\title{
Strain differences in shuttle avoidance conditioning in the rat
}

\author{
GORDON M. HARRINGTON \\ University of Northern Iowa, Cedar Falls, Iowa 50613
}

\begin{abstract}
Conditioned responses in a shuttle avoidance apparatus were measured for 480 rats from 12 inbred strains: ACI, A990, A35322, F344, INR, IR, MNR/Har, MNRA, MR/Har, TS1, TS3, WAG. The results provide parametric data for methodological use and add to the standardization of these strains as behaviorally defined lines. Differences from previously reported data are discussed.
\end{abstract}

Warner (1932) originated the shuttle avoidance conditioning apparatus that was to become perhaps the most commonly used instrument for avoidance conditioning studies with the rat. A number of studies of strain differences in shuttle avoidance conditioning have been carried out with various strains (Broadhurst \& Levine, 1963a, 1963b; Levine \& Broadhurst, 1961, 1963; Nakamura \& Anderson, 1962; Sines, Cleeland, \& Adkins, 1962). Bignami (1965) carried out a two-way selection experiment creating the Roman highavoidance and Roman low-avoidance strains, which are now rather widely used. As one of a number of studies (Harrington, 1971a, 1971b, 1972, 1979a, 1979b, 1979c, 1979d, 1979e, 1979f, 1979g, 1979h; Harrington \& Hellwig, 1979a, $1979 \mathrm{~b}$ ) intended to provide standardization data for the 12 inbred strains of rats most frequently cited in the behavioral literature, this study provides parametric data on avoidance conditioning for those strains. The need for standardization of research animals has become a matter of increasing concern in recent years (International Committee on Laboratory Animals, 1971).

\section{METHOD}

\section{Subjects}

Subjects were 480 rats, 129-133 days of age, 20 animals of each sex within each of the following 12 inbred strains: ACI/Har, A990/Har, A35322/Har, F344/DuHar, INR, IR, MR/Har, MNR/Har, MNRA (formerly MNR-a/Har), TS1, TS3, WAG/Har. All lines are designated by the standard nomenclature for this species and are described in the fourth international listing (Festing \& Staats, 1973). Animals were bred and maintained at $25.5^{\circ} \mathrm{C} \pm 1.1^{\circ} \mathrm{C}$ and $40 \% \pm 5 \%$ relative humidity. Breeders and pups were housed under natural light cycle. Pups were handled for $1 \mathrm{~min}$ on alternate days from age 14 to 45 days. At 45 days, they were transferred to individual cages with 24-h light cycle. More detailed descriptions are available elsewhere (Harrington, 1968).

\section{Apparatus and Procedure}

Apparatus was a shuttle box of conventional dimensions. Exact dimensions are no longer available because of fire loss of equipment and records. Longitudinal metal bars $16 \mathrm{~mm}$ in diameter, $27 \mathrm{~mm}$ on center, provided a floor grid in each half. The grids for each half were independently switch connected to a scrambled matched-impedance $50-\mathrm{V}$ ac shock source. A lateral fence of roller skate wheels divided the box into halves. A 1829 stimulus light was mounted in each end panel. Programming presented light at alternate ends of the box each $1 \mathrm{~min}$ for $50 \mathrm{~min}$. In each half of the box, shock off accompanied light off and shock on was delayed $10 \mathrm{sec}$ following light onset. Animals were tested for one 50-min session. Conditioned avoidance responses were automatically recorded.

\section{RESULTS AND DISCUSSION}

The means and standard deviations of the number of conditioned avoidance responses are shown for each of the 12 strains in Table 1. The results are characterized by relatively high variance, which tends to obscure strain characteristics. The A35322, F344, INR, and TS3 strains appear to have been most efficient in acquisition of conditioned avoidance responses.

It is of some interest to observe that the performance of the MR line was superior to that of the MNR and MNRA lines, and that MR males were superior to MR females. These results are the reverse of those

Table 1

Shuttle Conditioned Avoidance Responses in 12 Inbred Strains of Rats

\begin{tabular}{|c|c|c|c|c|}
\hline \multirow[b]{3}{*}{ Strain } & \multicolumn{4}{|c|}{ Conditioned Avoidance Responses* } \\
\hline & \multicolumn{2}{|c|}{ Males } & \multicolumn{2}{|c|}{ Females } \\
\hline & Mean & SD & Mean & SD \\
\hline $\mathrm{ACI} / \mathrm{Har}$ & 5.5 & 9.5 & 6.4 & 11.9 \\
\hline A990/Har & 10.4 & 12.4 & 7.3 & 11.3 \\
\hline A35322/Har & 13.8 & 11.1 & 15.0 & 9.1 \\
\hline F344/DuHar & 13.1 & 15.9 & 14.4 & 16.8 \\
\hline INR & 18.8 & 12.9 & 12.4 & 13.3 \\
\hline IR & 3.1 & 1.6 & 7.0 & 9.7 \\
\hline MNR/Har & 9.0 & 7.3 & 4.5 & 5.1 \\
\hline MNRA & 8.8 & 10.8 & 6.5 & 11.9 \\
\hline $\mathrm{MR} / \mathrm{Har}$ & 15.2 & 13.4 & 6.8 & 6.8 \\
\hline TS1 & 10.2 & 9.6 & 12.0 & 12.9 \\
\hline TS3 & 15.2 & 9.8 & 15.9 & 12.3 \\
\hline WAG/Har & 11.9 & 13.2 & 4.7 & 7.4 \\
\hline
\end{tabular}


obtained during the development of the Maudsley lines when the nonreactive lines exceeded the reactive lines and reactive females exceeded reactive males in shuttle avoidance conditioning (Broadhurst \& Levine, 1963a, 1963b; Levine \& Broadhurst, 1961, 1963). The reasons for such reversal are not evident. Since strain by early handling interactions have been found by Levine and Wetzel (1963), it is possible that the present data may reflect differences in animal husbandry as well as genotype. It is also possible that the results can be attributed to use of a visual stimulus in the present study rather than an auditory stimulus. A visual stimulus provides directional cues, which could represent a relevant variable in differentiating strains in conditioning.

\section{REFERENCES}

Bignami, G. Selection for high rates and low rates of conditioning in the rat. Animal Behavior, 1965, 13, 221-227.

Broadhurst, P. L., \& Levine, S. Behavioral consistency in strains of rats selectively bred for emotional elimination. British Journal of Psychology, 1963, 54, 121-125. (a)

Broadhurst, P. L., \& Levine, S. Litter size, emotionality and avoidance learning. Psychological Reports, 1963, 12, 41-42. (b)

Festing, M., \& StaAts, J. Standardized nomenclature for inbred strains of rats. Transplantation, 1973, 16, 221-245.

HARRINGTON, G. M. Genetic-environmental interaction in "intelligence." I: Biometric genetic analysis of maze performance of Rattus Norvegicus. Developmental Psychobiology, 1968, 1, 211-218.

HARrington, G. M. Strain differences among rats initiating exploration of differing environments. Psychonomic Science, 1971, 23, 348-349. (a)

HARRINGton, G. M. Strain differences in rotating wheel activity of the rat. Psychonomic Science, 1971, 23, 363-364. (b)

HARRINGTON, G. M. Strain differences in open field behavior of the rat. Psychonomic Science, 1972, 27, 51-53.

HARRINGton, G. M. Strain differences in activity of the rat in a shuttle stabilimeter. Bulletin of the Psychonomic Society, 1979, 13, 149-150. (a)

HARRINGTON, G. M. Strain differences in activity of the rat using a home cage stabilimeter. Bulletin of the Psychonomic Society, 1979, 13, 151-152. (b)

HARRington, G. M. Strain differences in free operant leverpress levels in the rat. Bulletin of the Psychonomic Society, 1979, 13, 153-154. (c)

HARRINGton, G. M. Strain differences in light-contingent barpress behavior of the rat. Bulletin of the Psychonomic Society, 1979, 13, 155-156. (d)

HARRINGton, G. M. Strain differences in open-field behavior of the rat. II. Bulletin of the Psychonomic Society, 1979, 13, 85-86. (e)

HARRINGton, G. M. Strain differences in passive avoidance conditioning in the rat. Bulletin of the Psychonomic Society, 1979, 13, 157-158. (f)

HARRington, G. M. Strain differences in runway learning in the rat. Bulletin of the Psychonomic Society, 1979, 13, 159-160. (g)

HARRINGton, G. M. Strain differences in simple operant barpress acquisition to an auditory stimulus by rats. Bulletin of the Psychonomic Society, 1979, 13, 163-164. (h)

HaRrington, G. M., \& Hellwig, L. R. Strain differences in basal metabolism of behaviorally defined rats. Bulletin of the Psychonomic Society, 1979, 13, 165-166. (a)

Harrington, G. M., \& Hellwig, L. R. Strain differences in organ weights of behaviorally defined rats. Bulletin of the Psychonomic Society, 1979, 13, 167-169. (b)

International Commitee on Laboratory Animals. Defining the laboratory animal. Washington: National Academy of Sciences, 1971.

Levine, S., \& Broadhurst, P. L. Genetic and ontogenetic influences on emotional reactivity in the rat. Bulletin of the British Psychological Society, 1961, 44, 20-21.

Levine, S., \& Broadhurst, P. L. Genetic and ontogenetic determinants of adult behavior in the rat. Journal of Comparative and Physiological Psychology, 1963, 56, 423-428.

LeVIne, S., \& WeTZEL, A. Infantile experiences, strain differences and avoidance learning. Journal of Comparative and Physiological Psychology, 1963, 56, 879-881.

Nakamura, C. Y., \& ANDERson, N. H. Avoidance behavior differences within and between strains of rats. Journal of Comparative and Physiological Psychology, 1962, 55, 740-747.

Sines, J. O., Cleeland, C., \& Adkins, J. The behavior of normal and stomach lesion susceptible rats in several learning situations. Journal of Genetic Psychology, 1962, 101, 209-216.

WARNER, L. H. The association span of the white rat. Journal of Genetic Psychology, 1932, 41, 57-90.

(Received for publication January 16, 1979.) 